UNITED STATES DEPARTMENT OF THE INTERIOR

Harold L. Ickes, Secretary

GEOLOGICAL SURVEY

W. C. Mendenhall, Director

\title{
Bulletin 931-S
}

\section{MANGANESE DEPOSITS \\ IN THE PAYMASTER MINING DISTRICT IMPERIAL COUNTY, CALIFORNIA}

BY

JARVIS B. HADLEY

Strategic Minerals Investigations, 1941 (Pages 459-473)

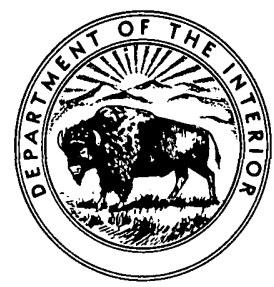

UNITED STATES

GOVERNMENT PRINTING OFFICE

WASHINGTON : 1942 

Abstract...................................



Geology ....................................

Rocks.................................

Structure...............................

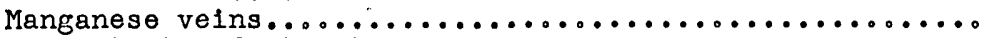

Extent and structure.......................

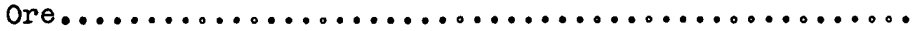

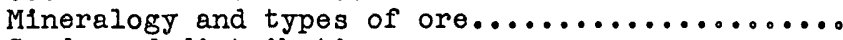

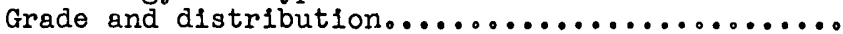

Origln..................................

Reserves...................................

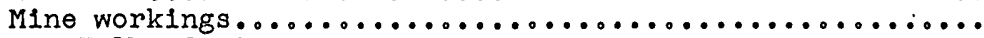

Tolbard mine...........................

Tres Amlgos workings.........................

Black Hill................................

Plate 75. Topographic and geologic map of the western part of the Paymaster manganese district, Imperial County, Calif................. In pocket 76. Veins and faults in the vicinity of the Tolbard and Tres Amigos workings........ In pocket 77. Plan and projection of workings, veins No. I and No. 2, Tolbard mine, Paymaster district, Caiff........................ In pocket

Figure 59. Index map of southeastern California showing location of the Paymaster manganese district............................

60. Types of vein materiai. A, Mammilary psilomelane on wall of vein; $\underline{B}$, Psilomelane breccia; $\underline{C}$, Fault breccia impregnated and re-

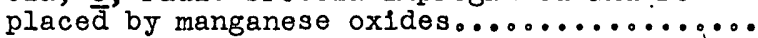

61. Diagrammatic sketch of typical vein struc-

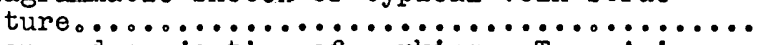

62. Plan and projection of workings, Tres Amigos

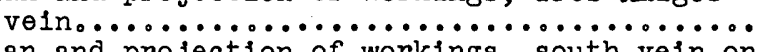

63. Plan and projection of workings, south vein on Black Hill......................... 



\title{
MANGANESE DEPOSITS
}

IN THE PAYMASTER MINING DISTRICT, IMPERIAL COUNTY, CALIFORIIA

\author{
By Jarvis B. Hadley
}

\section{ABSTRACT}

The manganese deposits of the Paymaster district, in Imperial County, Calif., extend along steeply inclined normal fault fissures which cut Tertiary (?) volcanic breccia and fanglomerate.

The ore deposits are in part open-space fillings composed largely of psilomelane, and in part fault breccia replaced by psilomelane, pyrolusite, and manganite. Calcite and rock fragments are the chief impurities. High-grade ore now exposed averages about 40 percent manganese, and contains much barium. About 3,000 tons of ore averaging 42 percent manganese was produced from the district by hand-sorting in 1917-18. It is estimated that nearly the same amount could be produced again, largely from present workings. In addition, a few tens of thousands of tons of milling ore, estimated to contain between 10 and 30 percent of manganese, are belleved to exist in veins one to three feet wide within one or two hundred feet of the surface。

\section{INTRODUCTION}

The Paymaster manganese district is in the northeast corner of Imperial County, Calif., 6 miles west of the Colorado River and about halfway between Blythe, Calif., and Yuma, Ariz. (fig. 59)。The manganese deposits are in secs. 16, 18, and 19, T. Il S., R. 21 E. By road they are 42 miles from Blythe and 54 miles from Yuma. Paved road extends 17 miles south from Blythe, and 10 miles northwest from Yuma. The remainder is graded earth road, with the exception of 6 miles of unimproved road extending from a point on the Blythe-Yuma road $2 \frac{1}{4} \mathrm{miles}$ north of Midway Well to the district. The nearest shipping 
point, Glamis on the Southern Pacific Rallroad, is 32 miles by earth roads southwest of the district. Ripley, 35 miles north on the road to Blythe, is on a spur of the Santa Fe Railroad.

The only sources of water in the district are some natural rock basins, which retain several hundred gallons for a few

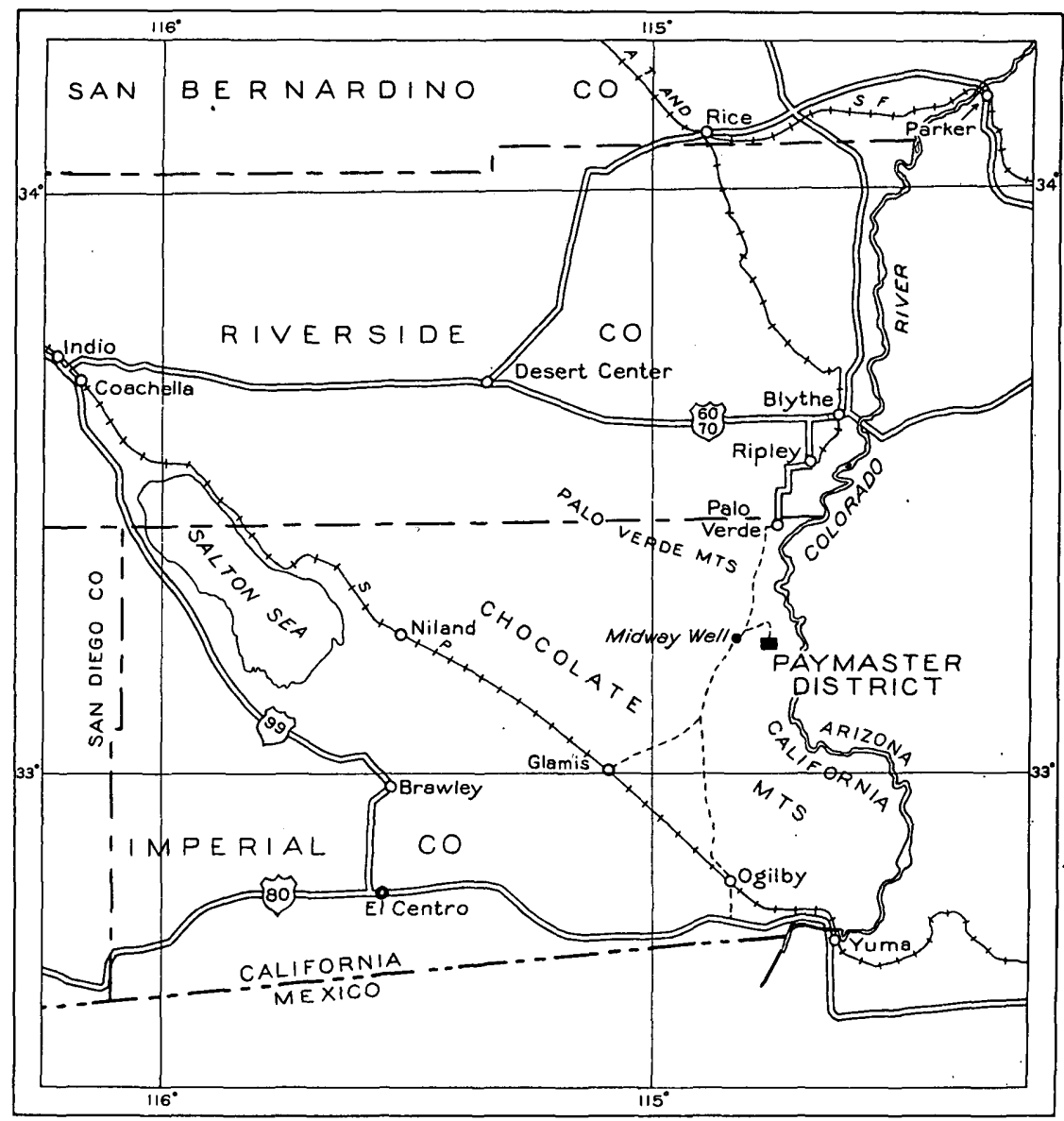

10,

\section{Fleure 59.-Index map of southeastern Callfornla, showing location of the Paymaster manganese district.}

weeks after hesvy ralns. The nearest dependable source at present is Midway Well, 8 miles from the properties. A spring $2 \frac{1}{2}$ mlles east-southeast of the Tolbard mine can be reached by unimproved road, and a well 2 miles due south of the mine is said to have been used in 1917-18. Only the western part of the 
district, which includes the deposits in sections 18 and 19, was mapped during this investigation; the fleld work was done in February and March 1941. John S. Livermore ably assisted in the fleld and in compling the maps. .C. H. Johnson of the Bureau of Mines, United States Department of the Interior, sampled some of the veins, and his results are used in this report. Helpful information was kindly given by Mr. V. B. Whedon of Beverly H1lis, Calif. F. C. Calkins and H. G. Ferguson offered many helpful suggestions in the preparation of the manuscript.

Manganese deposits were discovered in the western part of the district in 1916 and 1917, and were worked intensively durIng 1917 and 1918. Production records from published sources show that manganese ore produced in Imperial County, Calif., amounted to 1,907 tons valued at $\$ 38,140$ in 1917 , and 1,241 tons valued at $\$ 46,900$ in 1918.1 / Shipments from the Paymaster district account for most of this. Hewett $2 /$ reports that 3,500 tons of 42-percent ore were shipped. Shipments ceased late in 1918, and very little work has been done since.

The properties have recently been consolidated under the owmership of Mr. V. B. Whedon and associates of Beverly Hills, Calif. No work was being done in Febmuary and March 1941, but 15 tons of high-grade ore was mined by lessees in 1940.

Small deposits occur on what are known as the Turtle claims, In the eastern part of the district, but no ore is known to have been shipped from them.

\section{GEOLOGY}

The rocks of the Paymaster manganese district consist of a basement complex of schist, gnelss, and intrusive rocks, but these are overlain by volcanic rocks, which in turn are overlain

1/ Callfornia Min. Bur. Bull. 83, p. 39, 1918, and Bull, 86, p. 56, 1919. 5/ Hewett. D. F.. Ferrousmetal deposits, in uineral resources of the region around Boulder Dam: U. S. Geol. Survey Bul1. 871, p. 85, 1936. 
by 1,000 feet or more of coarse fanglomerate. (See pl. 75.) These rocks have been broken by many normal faults, at least three of which have displacements of several hundred feet. Others, of smaller displacement, contain the manganese deposits. Slightly consolidated boulder-bearing gravel, younger than the ore deposits, is widespread south and southeast of the area mapped, and extends into the area as fill in old erosion channels in the fanglomerate.

\section{Rocks}

The basement complex consists of intensely folded schist and gneiss cut by numerous dikes of fine-grained granite and by dikes and sills of pegmatite. These rocks make up the southern part of the range bordering: the district on the west (see pl. 75) and appear also at the east side of the district.

Dark reddish-gray andesite, 600 to 1,000 feet thick, rests with pronounced angular unconformity on the basement rocks in the western part of the district. Much of the andesite is flow breccia, and all of it is intensely fractured.

Coarse, indistinctly bedded, red fanglomerate occuples most of the district. It forms steep, irregular slopes, and massive rounded summits distinct from the jagged peaks and ridges typical of the region. The fanglomerate is composed largely of subangular fragments from a few inches to as much as 3 feet in diameter, with a minimum of coarse, pebbly matrix. Volcanic fragments predominate, and many are of the same type as the volcanic rocks now exposed. Other fragments, derived from the basement complex, are also abundant. Lenses of coarse, crossbedded sandstone, a few inches to a foot thick, are common throughout the formation but amount to less than 1 percent of the whole. The fanglomerate is well indurated and stands well in the mine workings. 
The fanglomerate lies on an 1rregular eroded surface of the andesite. The thickness of the fanglomerate in the district is at least 1,000 feet and may be considerably greater. Its age, like that of the andesite, is not definitely known; both are probably Tertiary. On the southern and southeastern borders of the area mapped, the eroded surface of the fanglomerate and older rocks is largely burled under slightly consolidated, bouldery gravel. The gravel forms smooth confcal hills as much as 100 feet high, among which 1solated outcrops of the more resistant fanglomerate appear. Similar gravel is found in old erosion channels in the vicinity of the Tolbard mine, where it is seen to be younger than the manganese veins.

St1ll younger materlal, unconsolldated, forms alluvial fans and the bottoms of the major valleys in the district.

\section{Structure}

There are three principal faults, all of them normal, and numerous subsidiary faults in the district. Two parallel major faults, trending north-northwest, cut off the fanglomerate on the west. The more westerly of these dips $50^{\circ}-60^{\circ} \mathrm{E}$. Along it, the fanglomerate and underlying volcanics have been thrown down at least 500 feet, bringing the fanglomerate locally against the basement complex. To the south, rocks of the complex lie on both sides of this fault, which is marked by coarse fault brecc1a from 15 to 50 feet wide. The stratigraphic displacement along the eastern fault is at least 100 feet at the north, and increases southward to at least 300 feet at Black H1ll.

The third major fault trends approximately at right angles to the other two and dips $50^{\circ} \mathrm{SSE}$. It cuts off the basement complex on the south and has a displacement of several hundred feet.

The fanglomerate and volcanics are broken by hundreds of minor faults, many of which are subsidiary to the major, normal 
faults. The minor faults strike northeastward and dip $60^{\circ}$ or more elther northwest or southeast. On most of them the displacement cannot be determined, but probably only a few have displacements exceeding a few tens of feet. Most of them are too small to appear on the geologic map (see pl. 75), but many are shown on the detailed map (pl. 76). The more persistent fissures contain several inches to a foot of fault breccia. Many of them, moreover, have been opened as a result of tension for considerable distances along their length, and contain pebbles and sand fallen from the walls. The impression was gained that the faulting occurred at rather shallow depth, possibly before the fanglomerate became as well indurated as it is now. Many of the minor fissures might be expected therefore to die out at no great distance below the present surface.

\section{MANGANESE VEINS}

\section{Extent and structure}

The manganese deposits are veins and stringers in minor fault fissures and assoclated fractures in both fanglomerate and andesite. The major faults are not mineralized, and no manganese deposits were found in the basement complex. The veins are most abundant in an area of about one-fourth square mile in the western part of the district, and in a much smaller area at the Turtle claims in the unmapped eastern part. The western veins are largely in fanglomerate; the princlpal eastern veins are in andesite.

Individual velns generally range in width from 1 inch to $2 \frac{1}{2}$ feet, although at a few places veins of greater width were seen. Only a fow velns extend more than two or three hundred feet; but zones of branching or overlapping fissures, in part mineralized, can be traced 2,500 feet. A good example is the Tres Amigos vein (pl. 75). Narrow, parallel veins 5 to 15 feet 
apart are comon, but are usually not spaced closely enough to permit the mining of several velns as a single ore body.

In the fanglomerate, veins that are nearly vertical have fairly well defined walls. Veins dipping about $60^{\circ}$ commonly have well-defined footwalls and gradational hanging walls, the latter of which are considerably mineralized.

Post-ore faulting has taken place on nearly all the larger veins and follows closely the preexisting fault fissures. The fault surfaces are smooth and locally striated, more or less parallel with the dip of the fault. They are surfaces of easy separation, and have been extensively used by the miners in breaking the ore.

\section{$\underline{\text { Ore }}$ \\ Mineralogy and types of ore}

The ore minerals are, in order of abundance: Psilomelane (manganese oxide with barlum, potassium, and water), pyrolusite $\left(\mathrm{MnO}_{2}\right)$, and manganlte $\left(\mathrm{Mn}_{2} \mathrm{O}_{3}\right.$ with water). Coarse-grained white calcite, finely divided carbonates, and chalcedony are the principal gangue minerals.

The manganese oxides flll open spaces in fault flssures, Impregnate and replace fault breccia, and impregnate and replace the flssure walls. Open-space flllings are composed principally of psilomelane and subordinate manganite in the form of mammillary layers (see f1g. 60, A) $1 / 8$ inch to 2 or 3 inches thick. Some of the psilomelane layers are porous and contain coarsegrained white calcite. This type of psilomelane is distributed In the veins in well-defined lenses, which range from 1 to 12 inches in width and from a few feet to 50 feet or more in length (flg. 6i). Such lenses are common, and where wide or numerous enough they constitute good ore. Many of them are too narrow to be mined singly. 
Much of the psilomelane, especially that adjacent to postore faults, is brecclated and cemented with pulverlzed oxides
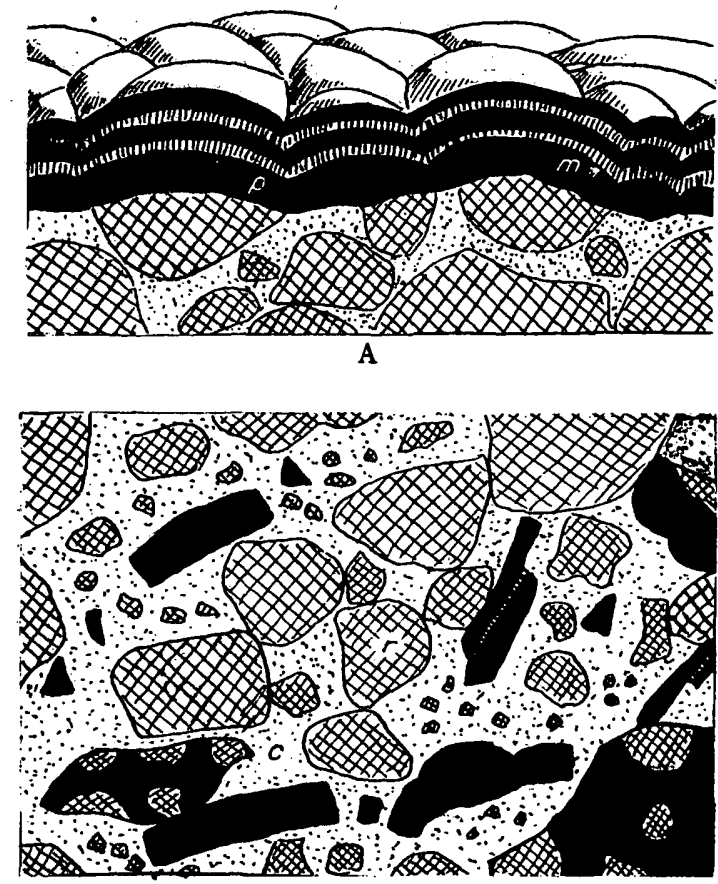

B

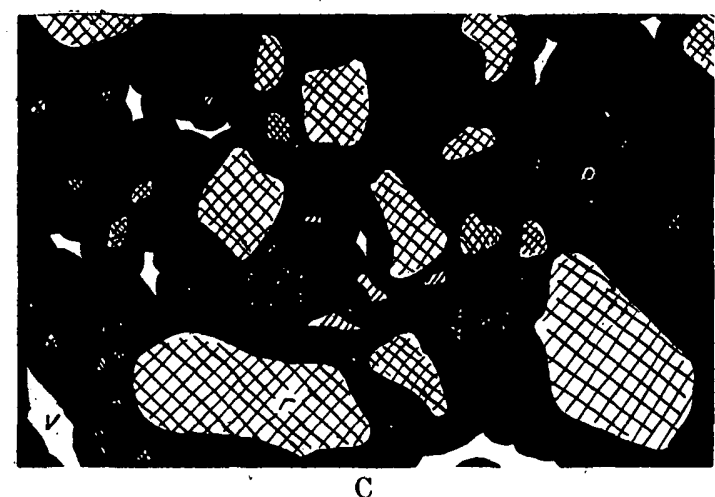

Heure 60.--Types of vein material. A, Mammillary psilomelane on tall of vein, oketched from hand soecimen, $\bar{x} \frac{1}{2} ; B$, Psllomelane brocela, $x \frac{1}{3}$; C, Fault breccla impregnated and replaced by manganese ox1dos, sketched

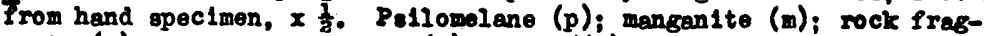
ments ( $r$ ); calcareous matrix (c); volds (v). 
and carbonates, and commonly contains more or less rock material. Lenses of "psilomelane-breccia", many feet long, contaln a few percent to 25 percent of psilomelane fragments an inch or more in diameter, mixed with rubble (figs。60, B and 61).

Most of the manganese deposits consist of mineralized fault breccia, which contains a considerable amount of rock material

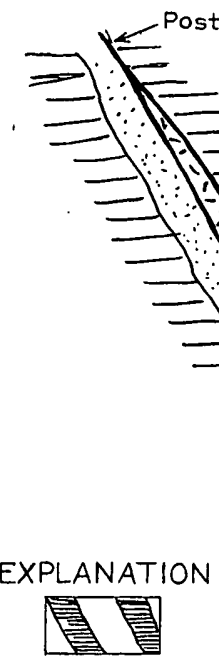

Mammillary psilomelane

$$
2,1-1,1
$$

Psilomelane breccia (Fragments of psilomelane in fault breccia or rubble)

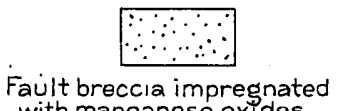
with manganese oxides

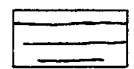

Fanglomerate



Figure 61.-Dlagrammatic sketch of typical vein structure.

In addition to the manganese oxides. The larger rock fragments are coated with, and partly replaced by psilomelane, which has completely replaced some of the smaller fragments. Interstices between fragments are filled by psilomelane, or mixed carbonate and soft manganese oxides (fig. 60, C). Interstices in some of the ore are coated with fibrous pyrolusite, or filled with whit 
calcite. Much of the mineralized fault breccia from veins in the fanglomerate resembles the "pudding ore" of manganese deposits in fanglomerate in New Mexico. $3 /$ In the andesite, fragments in mineralized fault breccla are more completely replaced, and soft manganese oxides are generally more abundant than psilomelane.

The walls of fissures in the fanglomerate are commonly impregnated with manganese oxides, but generally the amount of manganese is small. In andesite, however, the fissure walls are more thoroughly fractured and contain many thin seams of manganite and pyrolusite. In the main working on the southeast vein on Black Hill, a fissure zone 12 feet wide has been extensively replaced by manganese oxides.

\section{Grade and distribution}

A considerable quantity of ore shipped from the Tolbard mine is sald to have contained 46 percent manganese, 2.5 percent sil1ca, and 0.5 percent 1ron. $4 /$ This ore was hand-sorted, and average ore probably contains more silica. Analysis shows that the ore also contains much barium.

Ore mined from veins in the fanglomerate appears to have consisted principally of lenses of psilomelane and "psilomelane breccia", with some of the accompanying pudding ore. Most of the pudding ore apparently could not be hand-sorted to suitable grade, and no other method of concentration was used.

The best ore is in the widest and most persistent fissures, and most of it is in the princlpal veins at the Tolbard mine, the Tres Amigos vein, and the two veins on Black Hill. A few small bodies of high-grade ore are exposed at the surface in the cluster of veins 1,200 feet $S .60^{\circ} \mathrm{W}$. of the Tolbard shaft, in

3/ Lask, S. G., Manganese deposits in the Ifttle Florida Mountalns, Inna County, N. Lex.: U. S. Gool. Survey Bull. 922-C, pp. 62-64, 1940.

4 Jones, R. L., Jr., Deposits of manganese ore in southeastern California: o. S. Geol. Surrey Bull, 710, p. 207, 1920. 
two veins about 700 feet $N .60^{\circ} \mathrm{W}$. of the shaft, and in the Tres Amigos vein 1,100 feet north of the land survey section line. The ore shoots as revealed in underground workings (see pl. 77 and f1gs. 62 and 63), do not show any consistent shape or trend. The present distribution of ore bodies appears, however, to have resulted from three principal factors:

(1) Variable intensity of the original mineralization was presumably responsible for much of the unequal distribution of the manganese in the veins and for the fact that the mineralized fault breccia is generally richest where it is accompanied by psilomelane lenses. It is this factor primarily that limits the ore-bearing area, for conspicuous fissures extend considerably beyond the manganese veins.

(2) Open spaces, now filled with psilomelane, have resulted in part from separation of the fissure walls and in part from movement along irregular fault surfaces. Whether open spaces similarly colncide with changes in the dip of veins is not known. Some steeply dipping flssures, that have opened partly as a result of tension, like veln No. I at the Tolbard mine, contain unusually wide and persistent ore bodies.

(3) Displacements of ore bodies by post-ore faulting are common but not conspicuous because the post-ore faults follow the veins or cut them at very small angles. At many places lenses of psilomelane within the veins have been cut off and the width of the velns themselves materially affected by movements along these faults.

\section{Origin}

Good evidence of the downward migration of manganese is found in the Paymaster district in the form of stalagmitic crusts of psilomelane which coat vein walls and irregular surfaces within the velns. Such surfaces are commonly covered with vertical, upward-pointing cones of psilomelane as much as 
2 Inches high and 1 Inch thick. The upper surfaces of these cones are smooth and the lower surfaces are rough and botryoldal. They were formed presumably by solutions moving downward over surfaces exposed to the air at'a late stage in the history of the veins.

Apparently the veins have been enriched by supergene processes. Although no definitely hypogene manganese mineral or other vein mineral was found, supergene enrichment is characteristic of this type of deposit. The presence of hypogene black calcite, as well as white calcite, bearing manganese and iron in similar deposits in the Little Florida Mountains $5 /$ suggests that such material may also have been the original material in the Paymaster district. A lower limit to the manganese-oxide ore is therefore to be expected not far below the surface, although there is no evidence at present to indicate at what depth.

\section{RESERVES}

In estimating the reserves of manganese ore in the Paymaster district, two classes of ore may be considered:

(1) Submarginal ore bodies, of the type mined and shipped in 1917 and 1918, that could be hand-sorted to shipping grade should yield a moderate tonnage. These have a minimum width of 6 inches and are estimated by the writer to contain 40 percent or more of manganese. Twenty such ore bodies are exposed. With the exception of an ore body 150 feet long in the Tolbard mine, they range in length from 30 feet to 90 feet. Their aggregate length is 900 feet, two-thirds of which is exposed in the workings. It is estimated that known ore bodies of this type within 100 feet of the surface might yield from 2,000 to 3,000 tons. Prospecting for unexposed ore bodiss of this type would be both difficult and costly, for no reliable clues to their location have been established. 
(2) A considerably larger tonnage of milling ore may be expected. Veins from 1 to 3 feet wide aggregating 2,500 linear feet are exposed in the district and are estimated to contain from 10 to 30 percent of manganese. The amount of such ore in the district probably does not exceed a few tens of thousands of tons.

\section{MINE WORKINGS}

In the spring of 1941, underground workings on seven veins In the western part of the district totaled 1,660 linear feet. There were four shafts, with an average depth of 25 feet, and many open cuts and prospect pits.

\section{Tolbard mine}

The most extensive workings are at the Tolbard mine, where veing No. 1, No. 2, and No. 3 (see pl. 76) have been explored along the strike for 415 feet, 375 feet, and 40 feet respectively. On veins No. 1 and No. 2 , ore has been taken from overhead stopes 20-40 feet high and from underhand stopes 5-15 feet deep (pl. 77). These stopes are largely without timbering and are inaccessible because of their steep walls. They range in width from 4 feet to less than 1 foot. Most of them were opened only to the width of the vein, the ore breaking along post-ore faults at one or both sides. Aslde from the stopes, the workIngs consist chiefly of drifts along the veins. A crosscut from the shaft on vein No. 1, 30 feet below the collar, lacks a few feet of intersecting vein No. 2. Judging from the size of the stopes, about 1,300 tons of high-grade ore have been removed by underground workings from vein No. 1 , and about 500 tons from vein No. 2. Good ore is exposed at several places in the workings on both veins, leading to the belief that several hundred tons remain, principally in undeveloped ground below the drifts. 


\section{Tres Amigos workings}

About 100 tons of ore was taken from workings on the Tres Amigos vein, 1,150 feet due west of the Tolbard shaft (fig. 62). The principal vein is offset 5 feet horizontally by nearly vertical faults which cut the vein at small angles. The ore was taken from a drift 100 feet long and from a small stope. About 70 tons of ore are belleved to remain above the drift level.

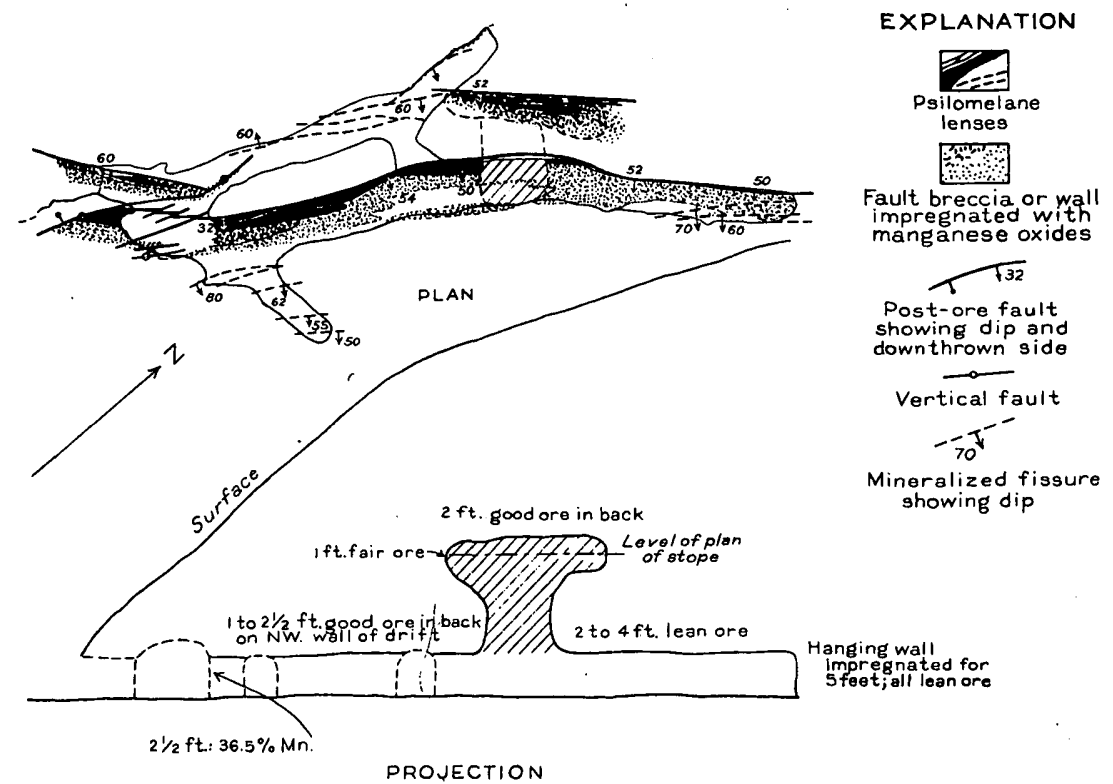
EXPLANATION O 40 Feet

Mgure 62.--Plan and projection of workings, Tres Amigos vein.

other workings on the Tres Amigos vein consist of three drifts, 100 feet or less in length, a small open stope, and two prospect shafts, 20 and 26 feet deep.

\section{Black H1ll}

The south vein in Black Hill (see fig. 63) has jielded about 200 tons of ore from a drift 75 feet long, a stope 28 feet high, and an open cut 43 feet long. The stope follows a zone 3-12 feet wide containing abundant fragments of andesite in a mixture of altered andesite and soft, brownish manganese oxides. 
The fragments are 8 inches or less in diameter, and much kaolin1zed. Considerable psilomelane is present in the drift and in the open cut above. A composite chlp sample $6 /$ taken at three places in the arift, across an average width of 18 inches, gave 38.7 percent manganese.

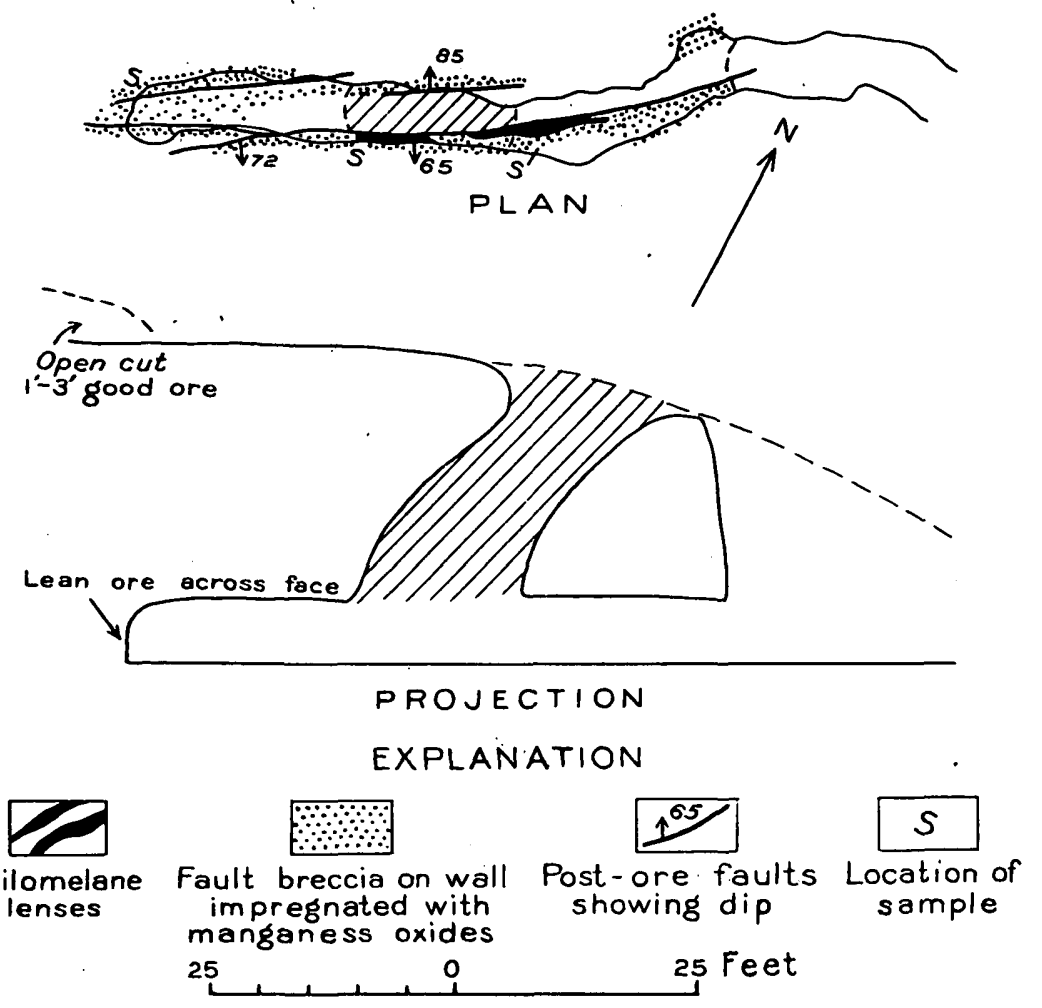

Floure 63.--Plan and profection of workines, south vein on Black Bill.

The upper drift on the north vein in Black H1ll encountered the bottom of a small body of high-grade psilomelane ore, which was stoped to an open cut 17 feet above. About 20 tons was removed, and 10 tons is believed to remain: Another drift on the same vein, 80 feet long and 47 feet lower, revealed slight mineralization but no ore.

6) Collected by U. S. Geol. Survey; analysis furnlshed by Bureau of Mines. 
Orton Memorial Library of Geolony 180 Orton Hall, $155 \mathrm{~S}$. Oval Mall

The Ohio State University

Columbus, $\mathrm{OH} 43210$

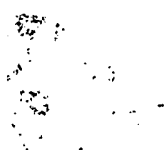

